\title{
THE INTERCEPTION AND RESCUE AT SEA OF ASYLUM SEEKERS IN THE LIGHT OF THE NEW EU LEGAL FRAMEWORK
}

\author{
SIMONE MARINAI ${ }^{1}$ \\ simone.marinai@unipi.it
}

Cómo citar/Citation

Marinai, S.(2016).

The interception and rescue at sea of asylum seekers

in the light of the new EU legal framework.

Revista de Derecho Comunitario Europeo, 55, 901-939.

doi: http://dx.doi.org/10.18042/cepc/rdce.55.04

\begin{abstract}
This paper deals with the evolving EU legal framework in order to verify to what extent it can be considered suitable for responding to the needs of asylum seekers intercepted or rescued at sea. In light of this goal, after examining the action carried out by the various actors engaged in the Mediterranean in operations for interception and rescue of asylum seekers, the international legal framework concerning the duty to render assistance to any person in distress at sea and the obligations deriving from human rights and refugee law are highlighted. The evaluation of the EU legal framework is carried out through an in-depth examination of the maritime operations coordinated by Frontex, taking into account in particular the evolution of the rules for the surveillance of external sea borders, and the new European Border and Coast Guard Regulation.
\end{abstract}

\section{Keywords}

Asylum seekers; rescue at sea; interception; European Union; Frontex; European Border and Coast Guard.

1 Full professor of International Law at the Italian Naval Academy of Livorno and associate professor of International Law at the University of Pisa. 


\section{LA INTERCEPTACIÓN Y EL RESCATE EN EL MAR DE LOS SOLICITANTES DE ASILO A LA LUZ DEL NUEVO MARCO JURÍDICO DE LA UNIÓN EUROPEA}

\section{Resumen}

Este trabajo analiza en qué medida el nuevo marco jurídico de la Unión Europea puede considerarse apropiado para abordar las necesidades de los solicitantes de asilo interceptados o rescatados en el mar. Teniendo en cuenta este objetivo, tras examinar la acción desarrollada por los distintos agentes implicados en las operaciones de interceptación y salvamento marítimo en el Mediterráneo, han sido analizados el marco jurídico internacional relativo a la obligación de ofrecer asistencia a las personas que se encuentren en peligro en el mar y las obligaciones que se derivan de los derechos humanos y del derecho internacional de los refugiados. La evaluación del marco jurídico de la UE se ha llevado a cabo mediante un estudio en profundidad de las obligaciones que tienen que respetar las operaciones marítimas coordinadas por Frontex a la luz de la evolución de las normas para la vigilancia de las fronteras marítimas exteriores y del nuevo Reglamento sobre la Guardia Europea de Fronteras y Costas.

\section{Palabras clave}

Solicitantes de asilo; rescate en el mar; operaciones de interceptación; Unión Europea; Frontex; Guardia Europea de Fronteras y Costas.

\section{L'INTERCEPTION ET LE SAUVETAGE DANS LA MER DES DEMANDEURS D'ASILE À LA LUMIÈRE DU NOUVEAU CADRE JURIDIQUE DE LA UNION EUROPÉENNE}

\section{Résumé}

Cet article analyse la façon dans laquelle le nouveau cadre juridique de l'Union européenne peut être considéré capable de répondre aux besoins des demandeurs d'asile interceptés ou sauvées en mer. Eu égard à cet objectif, après avoir examiné l'action menée par les différents acteurs impliqués dans des opérations d'interception et sauvetage dans la mer Méditerranée, est analysé le cadre juridique international concernant l'obligation de porter assistance aux personnes en détresse en mer et les obligations découlant des droits de l'homme et du droit international des réfugiés. L'évaluation du cadre juridique de l'UE est mise en œuvre au moyen d'une étude approfondie de les obligations à respecter par les opérations en mer coordonné par Frontex en raison de l'évolution des règles pour la surveillance des frontières maritimes extérieurs et du nouveau Règlement relatif au corps européen de garde-frontières et de garde-côtes.

\section{Mots clés}

Demandeurs d'asile; sauvetage dans la mer; interception; Union européenne; Frontex; Corps européen de garde-frontières et de garde-côtes. 


\section{SUMARIO}

I. MIGRATORY FLOWS THROUGH THE MEDITERRANEAN SEA. II. THE COEXISTENCE OF DIFFERENT KINDS OF OPERATIONS DEPLOYED IN THE MEDITERRANEAN SEA. III. THE DUTY TO RESCUE PERSONS IN DISTRESS AT SEA AND THE REQUIREMENTS OF REFUGEE LAW AND HUMAN RIGHTS LAW. IV. THE HUMAN RIGHTS ISSUES RAISED BY THE EU JOINT OPERATIONS AT SEA AND THE PROCESS OF REFORM OF FRONTEX. V. THE RULES FOR THE SURVEILLANCE OF THE EXTERNAL SEA BORDERS IN THE CONTEXT OF OPERATIONAL COOPERATION COORDINATED BY FRONTEX. VI. THE NEW EUROPEAN BORDER AND COAST GUARD: WHAT DOES IT CHANGE FOR ASYLUM SEEKERS?. VII. FINAL REMARKS.

\section{MIGRATORY FLOWS THROUGH THE MEDITERRANEAN SEA}

According to UNHCR data, in 2015 about one million migrants crossed the Mediterranean Sea and arrived to the southern cost of the European Union countries (mainly to Greece and to Italy)2. This figure is impressive in absolute terms, but also more striking if compared with the 2014 data when some 216,000 migrants reached Europe through the Mediterranean route.

Notwithstanding that the arrivals increased almost five-fold in 2015, UNCHR data also shows that in the same period the number of dead or missing during the crossing hasn't proportionally increased: in fact, while some 3,500 migrants did not arrive at destination during 2014, the number of dead/missing persons during 2015 reached 3,771.

2 Updated data on Mediterranean Sea arrivals are available at http://data.unhcr.org/ mediterranean/regional.php (this and all the following websites were last accessed on 20.10.2016). In 2015, UNHCR recorded 865,723 sea arrivals in Greece, 153,850 sea arrivals in Italy and 15,422 sea arrivals to Spain's Mediterranean shores. So far in 2016, UNHCR recorded some 320,000 Mediterranean sea arrivals to Europe. 
There is no doubt that during the last year the international community has demonstrated an unprecedented awareness of the need to cooperate in order to cope with this migration emergency. Therefore, many actors are operating across the Mediterranean with the aim of preventing the sea tragedies that have been taking place in recent years ${ }^{3}$. Certainly, the efforts made to save lives at sea have produced some positive results, but the problem is far from being resolved. At the same time, the mixed nature of the migratory flows arriving by sea, as well as the need to ensure special protection to asylum seekers must be considered.

In this regard, the obligations laying down the States participating to the interception and search and rescue operations have to be assessed.

In particular, this paper deals with the evolving EU legal framework in order to verify to what extent it can be considered suitable for responding to the needs of asylum seekers intercepted or rescued at sea ${ }^{4}$. In light of this goal, the coexistence of various actors engaged in the Mediterranean in interception and rescue operations of asylum seekers must be stressed (section II). Then, the duty to render assistance to any person in distress at sea has to be read jointly to the obligations deriving from human rights and refugee law (section III). Once the international legal framework will be established, it will be possible to analyze the human rights issues raised by the EU joint operations at sea and the progress they have made towards compliance with human rights obligations (section IV). In particular, the evolution of the rules for the surveillance of the external sea borders in the context of operations coordinated by Frontex (section V) and the new European Border and Coast Guard Agency which has recently replaced Frontex (section VI), will be taken into account in order to make an overall evaluation of the relevant EU legal framework (section VII).

3 Among the most shocking tragedies to be cited: on 3 October 2013, 368 migrants perished in a shipwreck off the coast of Lampedusa; on 18 April 2015, the capsizing of a trawler overcrowded with migrants while a Portuguese merchant ship approaching the vessel off the Libyan coast caused the death of at least 800 persons.

4 For an overview of the problematic issues raised by the migratory flows through the Mediterranean, see Giuseppe CATALDI, “Economic’ Migrants and Refugees: Emergencies (Real and Alleged) and the Law of the Sea», in ID. (ed.), A Mediterranean Perspective on Migrants Flows in the European Union: Protection of Rights, Intercultural Encounters and Integration Policies, Editoriale Scientifica, Naples, 2016, pp. 9-22. With regard to the EU's response to the refugee crisis, see Alejandro DEL VALLE, "Unión europea, crisis de refugiados y limes imperii», RGDE, núm. 38, 2016, pp. $1-13$. 


\section{THE COEXISTENCE OF DIFFERENT KINDS OF OPERATIONS DEPLOYED IN THE MEDITERRANEAN SEA}

A fair assessment of the situation should begin with an acknowledgment that many actors are currently engaged, across the Mediterranean Sea, in the various activities of border control, search and rescue, and combatting both human trafficking and migrant smuggling.

Border controls, as well as search and rescue operations, are still the responsibility of the individual coastal State. For this reason, the different national authorities deploy their own ships, aircrafts and assets 5 .

Mare Nostrum was an example of a commendable operation, almost entirely financed by the Italian government, deployed between October 2013 and October 2014, with the goal of enhancing the patrolling, surveillance and humanitarian rescue activities in the Mediterranean Sea. A distinctive feature of this operation is that it was carried out by the Italian Navy in international waters close to Libyan shores far beyond the Italian territorial waters, and the continuous zone. With this strategy, the risks connected to the long maritime journey taken by small, old and overcrowded vessels have been diminished. There is no doubt that the smugglers have adapted their strategies to bypass the new framework: the frequency of departures increased, the boats employed were smaller and carried less fuel, with the awareness that any rescue operations would take place just outside Libyan territorial waters. For this reason, voices have also been raised against Mare Nostrum: at an internal level by some Italian opposition parties, and at international level by other European countries (such as United Kingdom) which considered the operation a pull factor for migration towards Europe ${ }^{6}$. In any case, it is indisputable that by the end of its mandate, Mare Nostrum is reported to have saved the lives of some 160,000 migrants arriving by sea ${ }^{7}$.

5 The controls at border crossing points at ports are carried out by police authorities, while surveillance activities at sea are carried out by other forces, often of military or semi-military nature. For a more detailed picture of the distribution of competencies between the different national authorities in Greece, Italy, Malta and Spain, see FRA, Fundamental rights at Europe's southern sea borders, Publication Office of the EU, Luxembourg, 2013, pp. 41-42.

6 See Sergio CARRERA and Leonhard DEN HERTOG, "Whose Mare? Rule of law challenges in the field of European border surveillance in the Mediterranean", CEPS Paper, núm. 79, 2015, p. 4, available at https://www.ceps.eu/system/files/LSE_79. pdf.

7 See Report of the Special Rapporteur on the human rights of migrants, François CRÉPEAU, «Banking on mobility over a generation: follow-up to the regional study 
However, the enormous economic burden of the operation on Italy was no longer tenable. In fact, it is reported that Mare Nostrum cost the Italian treasury about 9 million euros per month — an unsustainably high burden on the Italian economy.

Mare Nostrum was subsequently replaced on 9th October, 2014 by the Frontex joint operation (JO) Triton. In its first accounting period, the budget of the operation was incomparable: in fact, the monthly budget was estimated at 2.9 million euros ${ }^{8}$. Also the operational area was more limited in comparison with that of Mare Nostrum. In fact, it is reported that the Frontex operation area didn't stretch more than 30 nautical miles beyond Italy's coast line? Following the tragedies of April 2015, the EU increased the Triton budged and, at the same time, extended its operational area to 138 nautical miles south of Sicily ${ }^{10}$. There is no doubt that this upgrading decreased the risk of shipwreck. Operation Triton rescued about 155,000 people between 1 January 2015 and 31 January 2016.

In the same period, Frontex was also involved in the Eastern Mediterranean. Through the JO Poseidon in particular, 107,000 people were rescued between the Greek and Turkish coasts ${ }^{11}$.

At the same time, Frontex has deployed the JOs EPN Indalo and Minerva with the aim of controlling the irregular migration flows from North African and Sub-Saharan countries towards the Southern Spanish coast. Both of these operations have been hosted by Spain with the operational support of several other Member States ${ }^{12}$.

on the management of the external borders of the European Union and its impact on the human rights of migrants», A/HRC/29/36, 8.5.2015, pp. 28.

8 See European Commission, «Frontex Joint Operation 'Triton' - Concerted efforts to manage migration in the Central Mediterranean», Press release, 7.10.2014, available at http://europa.eu/rapid/press-release_MEMO-14-566_en.htm.

9 See CARRERA and DEN HERTOG, «Whose Mare?...», op. cit. note 6, p. 9.

10 See Frontex, News, 26.5.2015, available at http://frontex.europa.eu/news/frontex-expands-its-joint-operation-triton-udpbHP.

11 See Communication from the Commission to the European Parliament and the Council, "on the State of Play of Implementation of the Priority Actions under the European Agenda on Migration», COM (2016) 85 final, 10.2.2016, p. 4.

12 Data of irregular migrants intercepted in 2014 and 2015 by the two operations are reported in Sergio CARRERA, Jean-Pierre CASSARINO, Nora EL QADIM, Medhi LAHLOU and Leonhard DEN HERTOG, «EU-Morocco Cooperation on Readmission, Borders and Protection: A model to follow?», CEPS Paper, núm. 87, 2016, p. 11, available at https://www.ceps.eu/system/files/EU-Morocco\%20Cooperation $\% 20$ Liberty\%20and\%20Security\%20in\%20Europe.pdf. 
Frontex joint operations, however, don't substitute for the Member States' obligations as regard monitoring and surveying the Schengen area's external borders, or guaranteeing full compliance with international obligations and particularly those concerning to search and rescue at sea.

It is well known that Frontex may coordinate operational cooperation between Member States in the Mediterranean as well as assisting Member States in circumstances requiring increased technical and operational assistance at the external borders, given that some situations may involve humanitarian emergencies and marine rescue. Furthermore, Frontex can set up European Border Guard Teams to be deployed during joint operations, pilot projects and rapid interventions. However, Frontex does not supplant the Member States obligations and constantly requires the contributions from Member States in terms of equipment, vessels and personnel.

The facilities recently provided by Norway, Ireland and Croatia are good examples of how such national contributions to Frontex operations carried out in the Mediterranean have been essential to saving lives at sea ${ }^{13}$.

On the contrary, the UK participation in Frontex operations caused controversy. During the extraordinary European Council in April 2015, the then UK Prime Minister, David Cameron, offered the warship HMS Bulwark, two patrol boats and three helicopters to the Frontex JO Triton, with the condition that deployment of those vessels and vehicles came with an assurance that any rescued migrants would be taken to Italy, or other nearby countries, rather than to the $\mathrm{UK}^{14}$.

Even after the HMS Bulwark was recalled, the UK dispatched the Oceanographic vessel HMS Enterprise under the different auspice of the EU's military operation EUNAVFOR MED ${ }^{15}$. This substitution has been regarded by some as a downgrading of the UK efforts ${ }^{16}$. In any case, it ought to be remembered that the UK government has repeatedly affirmed that the purpose of the resources deployed is not be to act in a proactive manner as search-and-

13 See e.g. Frontex, News, 15.9.2015, http://frontex.europa.eu/news/member-of-siempilot-crew-missing-since-monday-Njmd37.

14 See Melanie GOWER and Ben SMITH, «Mediterranean boat people», Briefing paper, House of Commons Library, núm. CBP 7210, 9.7.2015, p. 9, available at http:// statewatch.org/news/2015/jul/uk-hoc-briefing-med.pdf.

15 See https://www.gov.uk/government/news/hms-enterprise-to-replace-hms-bulwarkin-the-mediterranean.

16 See http://www.theguardian.com/world/2015/jul/27/hms-bulwark-replacement-hasyet-to-rescue-any-migrants-in-mediterranean. 
rescue, but rather to contribute to dismantling the network of smugglers and illegal traffickers ${ }^{17}$.

Operation EUNAVFOR MED was launched on 22 June 2015 within the framework of the European Common Foreign Security Policy (CFSP) ${ }^{18}$.

During its first phase, the aim of this military operation was to make a systematic effort to identify and monitor smuggling and trafficking networks through information gathering and patrolling on the high seas.

In its second phase, EUNAVFOR MED (in the meanwhile renamed operation Sophia) has been authorized to conduct boarding, search, seizure and diversion on the high seas, of vessels suspected of being used for human smuggling or trafficking. In particular, the legal framework that allowed for this shift to the second phase of the operation has been strengthened after the adoption of the United Nations Security Council (UNSC) Resolution 2240 $(2015)^{19}$ and the implementation of the same resolution at EU level ${ }^{20}$.

At present, this operation is being carried out on the high seas off the coast of Libya ${ }^{21}$. The possibility of preventing, investigating and prosecuting such acts within the Libyan territory and in its territorial sea is subordinate to Libya's request, and/or to wider authorization from the UN Security Council. However it must be considered that the latter will probably be opposed by Russia and China if Libya doesn't give its consent. What's more, Libya's consent won't be easily obtained, given the internal situation of that State,

17 See http://www.theguardian.com/world/2015/jun/23/uk-pulling-back-from-migrantrescue-with-hms-enterprise-deployment.

18 See Council Decision (CFSP) n. 2015/778 of 18 May 2015 on a European Union military operation in the Southern Central Mediterranean (EUNAVFOR MED) (OJ L 122, 19.5.2015, p. 31), and Council Decision (CFSP) n. 2015/972 of 22 June 2015 launching the European military operation in the southern Central Mediterranean (EUNAVFOR MED) (OJ L 157, 23.6.2015, p. 51).

19 See UNSC Resolution núm. 2240 of 9.10 .2015

20 See Political and Security Committee Decision (CFSP) 2016/118 of 20 January 2016 concerning the implementation by EUNAVFOR MED operation SOPHIA of United Nations Security Council Resolution 2240 (2015) (EUNAVFOR MED operation SOPHIA/1/2016) (OJ L 23, 29.1.2016, p. 63).

21 See Giuliana ZICCARDI CAPALDO, "The EUNAVFOR MED Operation and the Use of Force», ASIL Insight, vol. 19, núm. 27, 2015, available at https://www.asil.org/ insights/volume/19/issue/27/eunavfor-med-operation-and-use-force. With regard to the problematic issue of the precise identification of the maritime zones in which the operation can take place, see Marco GESTRI, «Eunavfor Med: Fighting Migrant Smuggling Under UN Security Council Resolution 2240 (2015)», IybIL, 25, 2015, pp. 21-54, p. $36 \mathrm{ff}$. 
which is trying to recover from a civil war which divided the country under two opposing governments (one placed in Tobruk, one placed in Tripoli) and which only recently seems to have reached a turning point ${ }^{22}$.

There can be no doubt that operation Sophia plays an important role in saving lives at sea: it is reported that it has so far rescued over 24,800 people ${ }^{23}$. EUNAVFOR MED is not the only military operation being carried out in the Mediterranean Sea. In fact, since February 2016, NATO ships have been deployed in the Aegean Sea with the aim of monitoring migrant and smuggler movement in the waters between Greece and Turkey. The decision was taken under a joint German, Greek and Turkish initiative at a NATO meeting in Brussels which also outlined further security and deterrence measures calling for a heightened troop presence in the Alliance's eastern region. The reason behind the NATO initiative need to be understood in the context of the reciprocal diffidence between Greece and Turkey, and their unwillingness to cooperate at a bilateral level (and to have their waters patrolled by the other country's vessels) without the intervention of a third supranational partner.

The European Council has welcomed the NATO initiative and established that Frontex should cooperate closely with NATO ${ }^{24}$.

Although it is too soon to evaluate the real impact of NATO's operations, certain declarations by Secretary General Stoltenberg have been already criticized ${ }^{25}$. On 23 February 2016, he declared at the European Parliament that NATO agreed with Turkey that if the rescued people come from that country, then they will be returned to Turkey. If this declaration

22 See the Press Statement on Libya issued by the UN Security Council on 1.4.2016 and welcoming the arrival in Tripoli of members of the Presidency Council of the Government of National Accord on 30 March 2016, led by Prime Minister Fayez Serray, http://www.un.org/press/en/2016/sc12313.doc.htm.

23 See «EUNAVFOR MED: operation SOPHIA flagship ITS GARIBALDI rescued over on thousand migrants», Press release 001/2016, 30.8.2016 available at http:// eeas.europa.eu/csdp/missions-and-operations/eunavfor-med/pdf/pr0012016.pdf.

24 See European Council Conclusions, EUCO 1/16 of 19 February 2016, para. 6. On July 2016, Frontex and NATO Maritime Command signed standard operating procedures as reported by Communication from the Commission to the European Parliament, the European Council and the Council, «Third Report on the Progress made in the implementation of the EU-Turkey Statement», COM (2016) 634 final, 28.9.2016, p. 4.

25 See Thomas SPIJKERBOER, "The NATO pushbacks in the Aegean and international law», available at http://thomasspijkerboer.eu/thomas-blogs/the-nato-pushbacks-in-the-aegean-and-international-law/. 
of intent will be effectively followed, it could be interpreted a "push-back» practice that the ECtHR already declared to be contrary to art. $3 \mathrm{ECHR}$ and to the non-refoulement principle, as well as contrary to art. 4 of Protocol 4 to the ECHR which prohibits collective expulsions ${ }^{26}$.

The existence of a general (though fragmentary) environment of international cooperation of States in the operations of interception and rescue of migrants in the Mediterranean does not preclude individual States from carrying out similar operations.

For example, there is the Italian military mission named Mare Sicuro (Secure Sea), whose mandate is to patrol the seas off the Libyan coast as part of a national security and anti-terrorism effort, which during its operation has contributed to rescuing and saving many lives at $\operatorname{sea}^{27}$.

In many cases, the rescue operations are performed by different kinds of ships (public, private, civil, military and merchant) which occasionally find themselves in the path of the boat carrying the migrants.

Take for example the case of the Brazilian Navy's corvette Barroso which rescued 220 migrants in the Mediterranean Sea in September 2015. It had been sailing towards Beirut, in Lebanon, in the framework of the United Nations' Maritime Task Force (MTF-UNIFIL), when it received a distress signal from the Italian Maritime Rescue Coordination Centre (MRCC) warning of a sinking vessel, carrying immigrants going to Europe ${ }^{28}$.

And last, but not least, the very important role played by a few vessels from humanitarian NGOs must be highlighted. The first privately-funded

26 See Hirsi Jamaa and o. v. Italy [GC], núm. 27765/09, ECHR 2012. For a recent overview of the ECtHR case law on the subject matter, see Rossana PALLADINO, «La tutela dei migranti irregolari e dei richiedenti protezione internazionale (artt. 3, 5, 8 e 13 CEDU; art. 4 Protocollo 4)», in Angela DI STASI (a cura di), CEDU e ordinamento italiano. La giurisprudenza della Corte europea dei diritti dell'uomo e l'impatto nell'ordinamento italiano (2010-2015), Wolters Kluwer-CEDAM, Vicenza, 2016, pp. 167-203.

27 The operation Mare Sicuro has performed 514 SAR actions, rescuing 87,965 persons and arresting 380 human smugglers, only considering the period from April 2015 (when it was launched) to September 2015. See European Parliament, LIBE, Committee «Mission Report of the EP LIBE delegation to Lampedusa (Italy) on search and rescue, in the context of the strategic own-initiative report on "the situation in the Mediterranean and the need for a holistic EU approach to migration'», 17-18.9.2015, p. 5, available at http://www.polcms.europarl.europa.eu/cmsdata/upload/66ff0a0e-10a8-4825-acee-4c6241113a5a/1075140EN.doc.

28 See http://agenciabrasil.ebc.com.br/en/internacional/noticia/2015-09/brazilian-navys-corvette-rescues-migrants-mediterranean-sea. 
search-and-rescue operation was carried out by MOAS (Migrant Offshore Aid Station). Other vessels have been deployed by Médecins Sans Frontiéres (MSF) and by SeaWatch. These make an outstanding contribution in the search and rescue of migrants and have offered a solid and invaluable support to the institutional actors.

\section{THE DUTY TO RESCUE PERSONS IN DISTRESS AT SEA AND THE REQUIREMENTS OF REFUGEE LAW AND HUMAN RIGHTS LAW}

The above-mentioned framework shows how complicated trying to reconstruct a coherent picture can be, considering all the actors involved, as well as the different objectives they are pursuing.

A uniting factor of those operations is represented by the need to respect the international obligations as regards the duty to render assistance to any person found to be in distress at sea and derived from human rights and refugee law ${ }^{29}$.

There is no doubt that the general obligation to render assistance to those in distress at sea is part of customary law and applies to every (be it military, civil, public or private) vessel regardless of the nationality of those being rescued, or the maritime zone where they have been found. This rule is well expressed in art. 98 para. 1 of the 1982 United Nations Convention on

29 With regard to the obligation to render assistance to people in distress at sea, see Martin SCHEININ (in collaboration with Ciaran BURKE and Alexandre Skander GALAND), «Rescue at Sea - Human Rights Obligations of States and Private Actors, with a Focus on the EU's External Borders», RSCAS Policy Paper, núm. 15, 2012, available at http://cadmus.eui.eu/bitstream/handle/1814/22389/RSCAS_ PP_2012_05.pdf?sequence=1; Marcello DI FILIPPO, «Irregular Migration and Safeguard of Life at Sea: International Rules and Recent Developments in the Mediterranean Sea», in Angela DEL VECCHIO (ed.), International Law of the Sea: Current Trends and Controversial Issues, Eleven International Publishing, The Hague, 2013, pp. 9-28; ID., «Irregular Migration Across the Mediterranean Sea: Problematic Issues Concerning the International Rules on Safeguard of Life at Sea», Paix et Sécurité Internationales, núm. 1, 2013, pp. 53-76.

With regard to the obligations deriving by refugee law and their application in case of rescue at sea, see Chiara FAVILLI, "La gestion difficile des flux migratoires pour un État situé à la frontière maritime extérieure de l'Union Européenne», $A F D I, 2013$, pp. 257-288, para. 3; Violeta MORENO-LAX, «Seeking Asylum in the Mediterranean: Against a Fragmentary Reading of EU Member States' Obligations Accruing at Sea», IJRL, 2011, pp. 174-220; Seline TREVISANUT, «The Principle of Non-Refoulement And the De-Territorialization of Border Control at Sea», LJIL, 2014, pp. 661-675. 
the Law of the Sea (UNCLOS), and in several other international law of the sea instruments ${ }^{30}$.

The recent practice reported above demonstrates that the duty to render assistance to people in distress at sea allowed for the rescue of thousands of immigrants trying to cross the Mediterranean Sea.

Rescue operations have been performed variously by single States (see for example the Italian operations, Mare Nostrum or Mare Sicuro), by Frontex operations whose primary objective was the control of external borders (see JOs Triton, Poseidon, Indalo) and by military missions (EUNAVFOR MED or NATO operations) whose main goal was the dismantling of the networks of smugglers and combatting human trafficking.

The significant contribution afforded by commercial vessels in saving lives at sea should not be underestimated ${ }^{31}$. And they do so despite the risks and the financial losses that commercial vessels are forced to bear. In fact, a request of assistance from a ship in distress may entail the need to divert from the original route, with more costs in terms of fuel, time and personnel. In addition to this, giving assistance to a ship full of migrants could be misunderstood by the public authorities that may, in some cases, incriminate the commercial vessel for what may wrongly be viewed as assisting illegal immigration. This kind of reasoning might often convince a commercial vessel to ignore the distress call or even, in the most regrettable cases, also to repel migrant boats back to the high seas or towards another coast ${ }^{32}$.

Lastly, the intervention of vessels deployed by NGOs (Médecins Sans Frontiéres, MOAS, SeaWatch) represents a concrete contribution to the activity of searching for and rescuing those in perils at sea.

The international efforts carried out during the last year and the extension of the field of operations towards the external borders of the international waters, closer to the shores of the countries of departure of the migratory flows, has contributed, without any doubt, to increasing the number of persons rescued at sea.

30 See, e.g.: 1974 Convention for the Safety of Life at Sea (SOLAS), Annex, Chapter V, Regulation 10; 1979 International Convention on Maritime Search and Rescue (SAR Convention), Annex, Chapter 2, at 2.1.10); 1989 International Convention on Salvage, Art. 10.

31 According to IOM data - available at https://www.iom.int/sites/default/files/infographic/Mediterranean-Rescue-Operations-15June.pdf — in the period between 1 January and 11 June 2015, commercial vessels rescued over 14,500 migrants.

32 These risks are highlighted, e.g., by Tamara LAST and Thomas SPIJKERBOER, «Tracking Deaths in the Mediterranean", in Tara BRIAN and Frank LACZKO (eds.), Fatal Journeys. Tracking Lives Lost during Migration, IOM, Geneva, 2014, p. 85-106, p. 91. 
This increase has an obvious knock-on effect on the management of the migrants and in particular of the asylum seekers.

First of all, migrants rescued at sea must be identified and then, if they claim to be refugees or they indicate that they fear persecution or ill-treatment if disembarked at a particular country, they must be directed to the State responsible for admission and processing of the asylum application.

It is evident that the ship's master is not the competent authority to determine the status of those who fall under his (or her) temporary care after a rescue operation ${ }^{33}$. Also, in the UNHCR's view, the identification and subsequent processing of asylum-seekers is an activity that is to be carried out most appropriately on dry land: on board it is difficult to provide an adequate access to translators, to safeguard the privacy of the applicants, to provide appropriate appeal mechanisms ${ }^{34}$. It must be excluded that such a burden should be placed on a commercial vessel that has occasionally rescued migrants during its journey. For all the above reasons, the recent proposal announced by the Italian Minister of Home Affairs, according to which new hotspots for the identification, registration and fingerprinting of migrants would be activated on board dedicated vessels ${ }^{35}$, raises concerns. There is no doubt that the rights of asylum seekers would be better guaranteed on the territory of the country of disembarkation.

A problem might arise with regard to the determination of the State of disembarkation. The controversial issue relating to the identification of a place safe for disembarkation is well known ${ }^{36}$.

The attempt to clarify the duties of countries involved in rescue operations that was carried out through the 2004 amendments to the 1974 Convention for the Safety of Life at Sea (SOLAS Convention) and to the 1979 International

33 See UNHCR, Background Note on the Protection of Asylum-Seekers and Refugees Rescued at Sea, 18.3.2002, para. 17, available at http://www.refworld.org/docid/3cd$14 \mathrm{bc} 24 . \mathrm{html}$.

34 See again UNHCR, Background Note, op. cit. note 33, paras. 23-25.

35 See http://www.ansa.it/sito/notizie/mondo/europa/2016/04/27/alfano-con-ue-attivare-hotspot-in-mare_001e68ed-9f50-4b2a-81b4-068d58b453d1.html. The proposal of floating hotspots has been the subject of an European Parliamentary question to the European Commission, P-004213/2016, 26.5.2016. On 10.8.2016, the Commission answered that clarifications on this matter are pending from the Italian authorities.

36 See e.g. Jasmine COPPENS and Eduard SOMERS, "Towards New Rules on Disembarkation of Persons Rescued at Sea?», The International Journal of Marine and Coastal Law, núm. 25, 2010, pp. 377-403, p. 385 ff.; MORENO-LAX, op. cit. note 29, pp. 196-200; DI FILIPPO, "Irregular Migration and Safeguard of Life at Sea...», op. cit. note 29, pp. 19-22. 
Convention on Maritime Search and Rescue (SAR Convention) ${ }^{37}$ did not solve all the doubts. In fact, the affirmation of the primary responsibility for ensuring disembarkation on the contracting State responsible for a search and rescue region in which the persons in distress have been rescued, doesn't infer in any case that the disembarkation must happen in the territory of that State. Further, it should be taken into account that not every State has accepted the above mentioned amendments ${ }^{38}$. The position of Malta - it maintains that rescued persons have to be disembarked at the closest safe port that, in many cases, doesn't mean to a port of its own wide SAR area - is well known.

In any case, the place of disembarkation must be «safe». This concept should not be interpreted in a restricted way, i.e. limited to the immediate needs of the rescued people, such as the need to receive medical treatment, shelter, food and water. Rather, the correct interpretation of this concept should be in line with international refugee law and, thus, with the non-refoulement principle. The latter doesn't impose on a State that it must accept the disembarkation of the migrants rescued at sea. Notwithstanding this, it does entail that the asylum seekers not be transferred to a State where they could risk to being subjected to persecution, or to be repelled to another country where such a risk would be concrete.

\section{THE HUMAN RIGHTS ISSUES RAISED BY THE EU JOINT OPERATIONS AT SEA AND THE PROCESS OF REFORM OF FRONTEX}

During its first years of activity, the joint operations at sea coordinated by Frontex have often been criticized ${ }^{39}$. The practice followed by Frontex was

37 See the Resolutions MSC.153(78) and MSC.155(78) adopted by IMO Maritime Safety Committee on 20 May 2004 and entered into force on 1 July 2006.

38 With regard to the amendments to the SOLAS Convention adopted by resolution MSC.153(78), as at 31.12.2005, three objections were communicated (by Finland, Malta and Norway) to the depositary of the Convention. However, Finland declared that it intended to accept the amendments as soon as the legislative amendments necessary to such acceptance have been carried out and to withdraw its objection so that the amendments could enter into force for Finland on 1.7.2006. On 5.7.2006, Norway withdrew its objection. With regard to the amendments to the SAR Convention adopted by resolution MSC.155(78), the depositary of the Convention received only the declarations of Malta and Norway, and the latter withdrew its objection on 5.7.2006.

39 See Parliamentary Assembly of the Council of Europe, Committee on Migration, Refugees and Displaced Persons, «Frontex: human rights responsibilities», report by 
perceived as opaque at least in some cases and its modus operandi has been considered similar to interdiction programs. This attitude has been found, for example, with regard to operations HERA II and HERA III, carried out by Frontex in 2006 employing resources from Spain, Finland, Italy and Portugal, and with the aim of enhancing EU control of the area between the West African coast and the Canary Islands ${ }^{40}$. During those operations, any intercepted people were diverted back to their port of origin. In particular, it seems that in 20085,969 migrants have been returned to the shores of Senegal and Mauritania. However, it is not clear if Spanish, Senegalese and Mauritanian authorities have guaranteed the respect of the human rights of those migrants. As the procedures of interception at sea are not plain, it is not possible to know the way the boats loaded with migrants have been diverted from their original route and returned to the coast. It is not possible to know if it has been granted the possibility to apply for asylum and, in general, which treatment has been reserved to the transferred people. Sources of Frontex says that Mauritanian or Senegalese officers have been always present on board of member States' boats, but Spain and other member States remain responsible for guarantying the respect of human rights during those operations ${ }^{41}$.

The criticism expressed to Frontex convinced the EU institutions and Frontex itself to begin a process of reflection and reform of the Agency's functions in order to achieve a more consistent compliance with human rights obligations during its operations.

In order to reinforce the commitment of Frontex to the respect for, as well as the promotion of, human rights in its activities, in 2011 Frontex formalized a Fundamental Rights Strategy, implemented by an Action Plan ${ }^{42}$.

Mr. Mikael CEDERBRATT, Doc. 13161, 8.4.2013. The first practice of the border surveillance operations led by Frontex in the Mediterranean is considered, for instance, by Giandonato CAGGIANO, «Attività e prospettive di intervento dell'Agenzia Frontex nel Mediterraneo", in Ennio TRIGGIANI (a cura di), Europa e Mediterraneo. Le regole per la costruzione di una società integrata, XIV Convegno SIDI, Bari, 18-19 giugno 2009, Editoriale Scientifica, Naples, 2010, pp. 403-428.

40 See Seline TREVISANUT, «The Principle of Non-refoulement at Sea and the Effectiveness of Asylum Protection", MPYUNL, núm. 12, 2008, pp. 205-246, pp. 244245; MORENO-LAX, op. cit. note 29, pp. 180-182.

41 See Parliamentary Assembly of the Council of Europe, Committee on Migration, Refugees and Population, "The interception and rescue at sea of asylum seekers, refugees and irregular migrants», Report by Mr. Arcadio DÍAZ TEJERA, Doc. 12628, 1.6.2011, para. 47.

42 See http://frontex.europa.eu/assets/Publications/General/Frontex_Fundamental_Rights _Strategy.pdf. The idea of an emerging "common model of humanized security at sea» 
At the same time, the Regulation establishing Frontex was amended ${ }^{43}$ placing on the Agency an obligation to draft and further develop a Code of Conduct to be applicable to all operations coordinated by the Agency, and intended to guarantee the principle of the rule of law and respect for fundamental rights, and among these, the rights of persons seeking international protection. Following the provision of the same amending Regulation, Frontex opened a Consultative Forum on Fundamental Rights (composed of representatives of 15 organisations, including EU Agencies, international organisations and NGOs) and appointed an independent Fundamental Rights Officer (FRO), both now operational since the end of 2012 .

During this process of increasing awareness of the need to enhance the fundamental rights obligations of Frontex, an important role has also been played by the EU Ombudsman. In fact, with two subsequent own-initiative inquiries $^{44}$, the Ombudsman has opened a fruitful dialogue with the Agency and stimulated further improvement of the rights of migrants and asylum seekers. However, not every issue has been resolved. In particular, in its Decision, adopted on 12 November 2013, the EU Ombudsman affirmed that the Frontex Fundamental Rights Strategy does not clarify the Agency's responsibility for possible infringements of fundamental rights which might occur in the course of its operations. In fact, Point 13 of the Strategy provides that "Member States remain primarily responsible for the implementation of the relevant international, EU or national legislation and law enforcement actions undertaken in the context of Frontex coordinated operations (including Rapid Border Intervention Teams, Joint Return Operations and Pilot Projects)» and that «this does not relieve Frontex of its responsibilities as the coordinator and it remains fully accountable for all actions and decisions under its mandate». According to the EU Ombudsman, it is not clear what the precise responsibilities

is stressed by Jorge Antonio QUINDIMIL LÓPEZ, «La Unión europea, Frontex y la seguridad en las fronteras marítimas. ¿Hacia un modelo europeo de seguridad humanizada en el mar?, RDCE, núm. 41, 2012, pp. 57-118.

43 See Regulation (EU) 1168/2011 of the European Parliament and of the Council of 25 October 2011 amending Council Regulation (EC) 2007/2004 establishing a European Agency for the Management of Operational Cooperation at the External Borders of the Member States of the European Union (OJ L 304, 22.11.2011, p. 1).

44 The first inquiry was launched on 6.3.2012 and was closed by the Decision of the EU Ombudsman of 12.11.2013, OI/5/2012/BEH-MHZ, available at http://www. ombudsman.europa.eu/en/cases/decision.faces/en/52477/html.bookmark. The second inquiry was launched on 20.10.2014 and was closed by the Decision of the EU Ombudsman of 4.5.2015, OI/9/2014/MHZ, available at http://www.ombudsman. europa.eu/en/cases/correspondence.faces/en/58135/html.bookmark. 
of Frontex as a coordinator are in relation to the issue of compliance with fundamental rights.

In the same Decision, the EU Ombudsman, having noted that Frontex had adequately addressed her recommendations, stresses the still open issue of the need to introduce an individual complaint mechanism regarding infringements of fundamental rights in the course of Frontex operations. To this end, the EU Ombudsman prepared a Special Report to the European Parliament ${ }^{45}$ and this latter, on 2 December last, adopted a resolution supporting the introduction of such a mechanism ${ }^{46}$. The mechanism has been provided by the draft Regulation of the European Parliament and the Council on the European Border and Coast Guard ${ }^{47}$ that replaced the Frontex Regulation from October 2016.

\section{THE RULES FOR THE SURVEILLANCE OF THE EXTERNAL SEA BORDERS IN THE CONTEXT OF OPERATIONAL COOPERATION COORDINATED BY FRONTEX}

The need for clear rules of engagement for joint patrols coordinated by Frontex, as well as rules on the disembarkation of rescued persons, convinced the Council of the EU to adopt Decision 2010/252 $2^{48}$. While the Decision mainly dealt with border surveillance issues, the issues related to interception operations and disembarkation in SAR operations were treated through

45 See Special Report of the European Ombudsman in own-initiative inquiry OI/5/2012/ BEH-MHZ concerning Frontex, 12.11.2013, available at http://www.ombudsman. europa.eu/en/cases/specialreport.faces/en/52465/html.bookmark.

46 See European Parliament resolution of 2 December 2015 on the Special Report of the European Ombudsman in own-initiative inquiry OI/5/2012/BEH-MHZ concerning Frontex, P8_TA(2015)0422.

47 See art. 72 of Regulation (EU) 2016/1624 of the European Parliament and of the Council of 14 September 2016 on the European Border and Coast Guard and amending Regulation (EU) 2016/399 of the European Parliament and of the Council and repealing Regulation (EC) 863/2007 of the European Parliament and of the Council, Council Regulation (EC) 2007/2004 and Council Decision 2005/267/EC (OJ L 251, 16.9.2016, p. 1).

48 Council Decision 2010/252/EU of 26 April 2010 supplementing the Schengen Borders Code as regards the surveillance of the sea external borders in the context of operational cooperation coordinated by the European Agency for the Management of Operational Cooperation at the External Borders of the Member States of the European Union (OJ L 111, 4.5.2010, p. 20). 
non-binding guidelines included in the same Decision. However, in the binding part of the Decision, the Council affirmed that no person shall be disembarked in, or otherwise handed over to the authorities of, a country in contravention of the principle of non-refoulement, or from which there is a risk of expulsion or return to another country in contravention of that principle. With this aim, the persons intercepted or rescued at sea shall be informed in an appropriate way so that they can express any reasons for believing that disembarkation in the proposed place would be in breach of the principle of non-refoulement ${ }^{49}$.

Notwithstanding these guarantees, the non-refoulement principle seems to be contradicted by the provision according to which measures taken in the course of the surveillance operations may include, inter alia, ordering the ship to modify its course out of or towards a destination other than the territorial waters or contiguous zone of the EU Member State; escorting the vessel or steaming nearby until the ship is heading on such course; conducting the ship or persons on board to a third country or to the authorities of a third country ${ }^{50}$.

In any case, the Decision was declared null and void by the European Court of Justice by its judgment of 5 September 2012 after the European Parliament had challenged its legality ${ }^{51}$. In fact, the Court stressed that the Decision provided important rules relating to Frontex operations at sea with potentially significant consequences for the human rights of migrants. And those rules were adopted not via the ordinary EU legislative procedure, but via the more opaque comitology procedure ${ }^{52}$.

Decision 2010/252 was later replaced by Regulation 656/2014 which was adopted, through an ordinary legislative procedure, by the European Parliament and the Council of the $\mathrm{EU}^{53}$.

49 See para. 1.2 of Part I to the Annex of the Decision.

50 See para. 2.4 lett. e) and f) of Part I to the Annex of the Decision.

51 See Judgment of the Court in European Parliament v. Council, C-355/10, EU:C:2012:516. For a comment to Decision 2010/252 and to the judgment of the CJEU, see Miguel Angel ACOSTA SÁNCHEZ and Inmaculada GONZÁLEZ GARCÍA, "Vigilancia de fronteras marítimas y elementos esenciales en los actos de ejecución», RDCE, núm. 47, 2014, pp. 267-284.

52 See Valsamis MITSILEGAS, The Criminalisation of Migration in Europe: Challenges for Human Rights and the Rule of Law, Springer, Cham-Heidelberg-New York-Dordrecht-London, 2015, p. $18 \mathrm{ff}$.

53 Regulation (EU) 656/2014 of the European Parliament and of the Council of 15 May 2014 establishing rules for the surveillance of the external sea borders in the context of operational cooperation coordinated by the European Agency for the Management of Operational Cooperation at the External Borders of the Member States of the European Union (OJ L 189, 27.6.2014, p. 93). For a comment, see, inter alios, Francina 
Also the new Regulation raised problematic issues, particularly with regard to the extension of the EU competences in the subject-matter.

In fact, six Member States (Cyprus, France, Greece, Italy, Malta and Spain) stressed that the issues related to maritime search and rescue and to disembarkation are regulated by international law and are the competence of the Member States. In their view, the EU didn't have a competence to legislate about these subjects and any rules that depart from those in the international regime would be unacceptable. Furthermore, the adoption of such rules would create an EU regime applicable to a Frontex-coordinated joint operation to run in parallel with the international regime and that would complicate the action of Member States and of their officers who would then be required to apply different rules depending on whether operation was coordinated by Frontex or not ${ }^{54}$.

However, the main scope of the position of these Member States was to avoid the application of the new rules to any operations they were carrying out unilaterally or, in any case, without the involvement of Frontex. This was proved by the circumstances whereby the crucial turning point in the easing of Member States' concerns was the reassurance that the SAR and disembarkation rules provided by the Regulation would be contained in the operational plans of each Frontex operation and, consequently, that they relate exclusively to that individual Frontex operation ${ }^{55}$.

There is no doubt that the Regulation takes steps forward with regard to the protection of fundamental rights and the respect of the principle of non-refoulement. The detailed affirmation of the principle of non-refoulement as set out

ESTEVE, «El rescate como nueva función europea en la vigilancia del Mediterraneo. Rescue as a new European role in the surveillance of the Mediterranean», Revista CIDOB d'Afers Internacionals, núm. 111, 2015, pp. 153-172.

54 See Council of the European Union, Proposal for a Regulation of the European Parliament and of the Council establishing rules for the surveillance of the external sea borders in the context of operational cooperation coordinated by the European Agency for the Management of Operational Cooperation at the External Borders of the Members States of the European Union - Position on Articles 9 and 10, 2013/0106 (COD), 14612/13, Brussels, 10.10.2013. The strong reaction of the above mentioned six Member States has been underlined by: Philippe DE BRUYCKER, Anna DI BARTOLOMEO and Philippe FARGUES, «Migrants smuggled by sea to the EU: facts, laws and policy options», MPC Research Report, núm. 9, 2013, p. 11, available at http:// www.migrationpolicycentre.eu/docs/MPC-RR-2013-009.pdf; Steve PEERS, «EU rules on maritime rescue: Member States quibble while migrants drown», 22.10.2013, p. 3, available at http://www.statewatch.org/analyses/no-243-eu-search-and-rescue.pdf.

55 In this respect, see CARRERA and DEN HERTOG, "Whose Mare?...", op. cit. note 6, p. 12. 
in art. 4 of the Regulation points in that direction. In particular, it is specified that according to that principle, no person shall be disembarked in, forced to enter, conducted to or otherwise handed over to the authorities of a country where there is a serious risk that he or she would be subjected to the death penalty, torture, persecution, other inhuman or degrading treatment or punishment, or where his/her life or freedom would be threatened. Nor may the individual be conducted to a country where he or she be at risk of expulsion, removal or extradition to another country in contravention of the principle of non refoulement.

According to the Hirsi ECtHR case-law ${ }^{56}$, the Regulation requires that the host Member State, in coordination with participating Member States and the Agency, shall evaluate the general situation in the third country of destination, and prevent the disembarkation if the latter is not considered safe. At the same time, the participating units shall use all means available to identify the intercepted or rescued persons, assess their personal circumstances, inform them of their destination, allowing them to express any reason for believing that disembarkation in the proposed place would be in violation of the principle of non-refoulement.

This attempt to meet the requirements of the ECtHR case law as set down in order to respect the principle of non-refoulement, art. 3 ECHR and the prohibition of collective expulsions deriving from art. 4 of Protocol 4 to the $\mathrm{ECHR}$, is evident from the text of the Regulation.

The final version of the Regulation makes clear that the guarantees provided for in its art. 4 shall apply to all measures taken by Member States or the Agency in accordance with the same Regulation ${ }^{57}$. This implies that the principle of non-refoulement must be respected not only during the operations being carried out in territorial waters or in contiguous zones, but also on the high seas. The need for such clarification was also required by $\mathrm{UNHCR}^{58}$, and has been welcomed as it codifies the interpretation that the ECtHR gave to the extraterritorial application of human rights obligations deriving from ECHR and thus to the principle of non-refoulement that must be respected

56 See Hirsi Jamaa, cit., note 26, para. $117 \mathrm{ff}$.

57 This specification, included in art. 4 para. 7, didn't appear in the original version of the proposal of Regulation, COM 2013(197).

58 See UNHCR comments on the Commission proposal for a Regulation of the European Parliament and of the Council establishing rules for the surveillance of the external sea borders in the context of operational cooperation coordinated by the European Agency for the Management of Operational Cooperation at the External Borders of the Member States of the European Union (Frontex) COM 2013 (197) final, at pp. 7-8, available at http://www.unhcr.org/534fd9e99.pdf. 
whenever a State exercises its jurisdiction through its agents, and this may also happen when operating outside of its territory, including on the high seas ${ }^{59}$.

Despite its positive points, many aspects of the Regulation remain open to criticism with regard to the protection of asylum seekers ${ }^{60}$.

In particular, in order to identify the intercepted or rescued persons, assess their personal circumstances, inform them of their destination, the Regulation - in art. 4 para. 3 - provides that further details shall be specified in the operational plan including, when necessary, the availability of shore-based medical staff, interpreters, legal advisers and other relevant experts of the host and participating Member States.

In this respect, it has been stressed that the operational plan is usually secret, and therefore it is not possible for democratic control over the procedures to be exercised. Limiting to the extent deemed "necessary» the provision of interpreters, legal advisers, and other staff and experts, gives rise to a margin of appreciation that fails to meet adequate standards when human rights of asylum seekers are at stake.

In any case, it is not clear if the assessment of the rescued person's individual situation should be done on board, or on dry land. As we have already considered, it is difficult to properly carry out on board the process of identification, and the subsequent processing of asylum-seekers ${ }^{61}$. On board, it would be hard to provide appropriate appeal mechanisms.

59 See Hirsi Jamaa, cit., note 26, paras. 70-82.

60 For a critical appraisal of the Regulation, see Emanuela PARISCIANI, «Search and rescue operations in the Mediterranean Sea and access to asylum: another 'Dublin'", JIANL, núm. 29, 2015, pp. 159-171, p. 163 ff.; Maarten DEN HEIJER, «Frontex and the shifting approaches to boat migration in the European Union: a legal analysis», in Ruben ZAIOTTI (ed.), Externalizing Migration Management. Europe, North America and the spread of 'remote control' practices, Routledge, Abingdon, New York, 2016, p. 53; Juan SANTOS VARA and Soledad RODRÍGUEZ SÁNCHEZ-TABERNERO, «In Deep Water: Towards a Greater Commitment for Human Rights in Sea Operations Coordinated by FRONTEX?», EJML, 2016, pp. 65-87.

61 Concerns about the adequacy of an individual assessment carried out during the operation at sea are expressed, amongst the others, by UNHCR comments, op. cit. note 58, p. 4. In fact, according to UNHCR, «Individual identification at sea should aim to establish individual circumstances and cannot result in a de facto admissibility procedure or substitute the asylum procedure. UNHCR would not be in favour of processing an application for international protection onboard a vessel». In the same vein see also Parliamentary Assembly of the Council of Europe, Committee on Migration, Refugees and Displaced Persons, "The 'left-to-die boat': actions and reactions", Report by Ms Tineke STRIK, Doc. 13532, 9.6.2014, para. 64. 
It is significant that the Regulation makes no reference to the obligation to guarantee access to an effective remedy that, on the contrary, according to the interpretation of art. 13 ECHR developed by ECtHR, requires an independent and rigorous scrutiny of any complaint made by the interested person who is at real risk of treatment contrary to his or her human rights, and the possibility of suspending the implementation of the measure impugned ${ }^{62}$.

Moreover, the provision according to which the units participating in the Frontex operation might order the vessel carrying the migrants to alter its course out of, or towards a destination other than, the territorial sea or the contiguous zone, doesn't seem to be in line with the principle of non-refoule$m e n t^{63}$. As has already been noted with regard to the corresponding provision previously included in Decision 2010/252, and notwithstanding the clearer affirmation of the obligation to respect the principle of non-refoulement, it is evident that giving an order not to enter the territorial sea or even escorting the vessel or steaming nearby it until it is confirmed that the vessel keeps on a different heading, this kind of conduct could hinder the forbidden practice of informal push-back.

One may wonder if the provisions of the Regulation also apply to operations that Frontex might carry out in the territorial sea of a third country, following the consent of this latter, as already happened during the above mentioned operations HERA II and HERA III coordinated by Frontex with the aim of enhancing control of migratory flows proceeding from the West African coast and directed towards the Canary Islands. In fact, the Regulation only provides rules pertaining to any interception in the territorial sea of a Member State, on the high seas and in the contiguous zone (articles 6, 7,8) and doesn't expressly regulate the case of operations carried out in the territorial sea of a third country. It is true that this pitfall could be solved by interpreting the Regulation in light of the 2011 amended version of the Frontex Regulation, according to which Frontex operations must respect EU law and the human rights of migrants even if cooperation takes place in a third State's territorial waters, and that this interpretation is clearly confirmed in Recital 5 of the Regulation ${ }^{64}$.

62 See e.g. Jabari v. Turkey, núm. 40035/98, \$ 50, ECHR 2000-VIII; Hirsi Jamaa, cit. note 26, para. 198.

63 See art. 6 para. 2 b) and art. 7 para. 2 b) which respectively regulate the case the vessel is intercepted inside the territorial sea or on the high seas.

64 See art. 14 para. 1 of the Regulation 2007/2004 as amended by Regulation (EU) 1168/2011 of the European Parliament and of the Council of 25 October 2011 
However, considering the sensitivity of this issue, the lack of a specific provision, affirming such a principle in the normative part of the Regulation as well, is cause for concern.

The attempt made towards the specification of the regime applicable to search and rescue operations and to the subsequent individuation of a safe place of disembarkation certainly appears to be positive. In particular, the Regulation establishes the conditions whereby the vessel might be considered to be in a phase of uncertainty, alert or distress ${ }^{65}$. In these cases, the units participating in a Frontex operation shall promptly transmit all available information to the Rescue Coordination Centre (RCC) responsible for the search and rescue region in which the situation occurs and they shall place themselves at the disposal of that RCC. While awaiting instructions from the RCC, participating units shall take all appropriate measures to ensure the safety of the persons concerned. The participating unit shall contact the RCC of the host Member State if the relevant RCC of a third country does not respond to a request of intervention, unless another internationally recognized RCC is better able to assume coordination of the search and rescue situation. This provision takes account of the practice during the rescue operations carried out in the Mediterranean that demonstrates, in many cases, a low level of cooperation by some third States. This is, precisely, what happened in the case of the MV Salamis, a Liberian flag tanker, that on $4^{\text {th }}$ August 2013, rescued 102 migrants from a boat in distress off the Libyan coast ${ }^{66}$. It is uncontested that in that case the responsible Libyan SAR authority failed to act, and that the management of the case was then assumed by the Italian Maritime RCC. More generally, the lack of cooperation by the Libyan SAR authorities was recorded by Frontex in the framework of JO Hermes 2014 deployed at the external sea borders of the Central Mediterranean region and hosted by Italy with the support of many EU and non-EU countries. In particular, the Maritime RCC of Italy is reported to have received many SAR requests from vessels in distress in Libyan SAR, to have entered in communication

amending Council Regulation (EC) 2007/2004 establishing a European Agency for the Management of Operational Cooperation at the External Borders of the Member States of the European Union (OJ L 304, 22.11.2011, p. 1). See CARRERA and DEN HERTOG, «Whose Mare?...», op. cit. note 6, p. 11. See Regulation 656/2014, art. 9 para. 2 lett. c), d), e).

66 The case has been in depth examined in all its multifaceted problems by Jean-Pierre GAUCI and Patricia MALLIA, Access to Protection: A Human Right, National report - Malta, 2013, especially at pp. 28-29 and $36 \mathrm{ff,} \mathrm{available} \mathrm{at} \mathrm{http://www.pfcmalta.}$ org/uploads/1/2/1/7/12174934/hirsi_report_final_1-12.pdf. 
with the Libyan SAR authorities, but no reply or cooperation was received, with the consequence that all the migrants rescued in the Libyan SAR were disembarked in Italy ${ }^{67}$.

The solution laid down in the Regulation, therefore, shall be considered in the context of this practice.

Concerning disembarkation ${ }^{68}$, the Regulation provides that, in the case of interception in the territorial sea or the contiguous zone, the coastal Member State shall allow the migrants to be transferred to its territory. In case of interception on the high seas, disembarkation may take place in the third country from which the vessel is assumed to have departed from, but if this solution is not possible, e.g. because that third country is not safe for asylum seekers or because that third country doesn't accept the return of the migrants, disembarkation shall take place in the Member State hosting the operation.

In case of search and rescue situations, all the countries involved in the Frontex-led operation shall cooperate with the responsible RCC to identify a place of safety and when the RCC designates such a place of safety, they shall ensure that disembarkation is carried out rapidly and effectively. As a closing provision, the Regulation provides that if it is not possible to arrange for the participating unit to be released from its obligation of search and rescue within a reasonable time, the disembarkation of the rescued persons shall be authorized by the host Member State.

The first practice that was recorded after the entry into force of the Regulation shows that this set of rules has the effect of disembarking the migrants intercepted or rescued at sea in the Member State hosting the Frontex operation.

In particular, the Frontex' report of July $2015^{69}$ recorded that all the migrants intercepted or rescued in the Mediterranean Sea in the framework of the operations EPN Hermes 2014 ${ }^{70}$, EPN Triton 2014 ${ }^{71}$, Poseidon

67 See Frontex' Annual Report on the implementation on the EU Regulation 656/2014 of the European Parliament and of the Council of 15 May 2014 establishing rules for the surveillance of the external sea borders, Warsaw, 9 July 2015, available at http:// frontex.europa.eu/assets/About_Frontex/Governance_documents/Sea_Surveillance/ Sea_Surveillance_report_2014.pdf, p. 6.

68 See art. 10 of the Regulation.

69 See Frontex' Annual Report, cit. note 67.

70 The operational area of EPN Hermes 2014 was established south of Sicily Island including the Pelagic Islands.

71 The operational area of EPN Triton 2014 was divided in six different areas in the Central Mediterranean Sea (south of Sicily Island including the Pelagic Islands; south of the island of Malta; east of Sicily; south of Sardinia; east of Puglia; east of Calabria). 
Sea $2014^{72}$, JO EPN Indalo $2014^{73}$, were disembarked in the host country (namely, respectively, Italy in the first two operations, Greece and Spain in the others). And this was despite the fact that the operational plans of two of those operations (Poseidon Sea 2014, JO EPN Indalo 2014) also provided for the possibility of disembarking the migrants in a in third country (respectively, Turkey and Morocco).

The criteria provided by the Regulation for disembarkation therefore create a significant burden on the State hosting the Frontex operation: in fact, the latter will have to manage the accommodation of any migrants with irregular status and will, in most cases, be the country responsible for examining the applications for international protection. This derives from the Dublin Regulation ${ }^{74}$, according to which the Member State whose territory the migrant has irregularly entered by sea having come from a third country, shall be generally $y^{75}$ responsible for examining the application for international protection. The obvious consequence thus is that some Member State might prefer to avoid assuming the responsibility of leading a Frontex operation. This is exactly the position taken by Malta that, after hosting operation Nautilius from 2006 to 2009, has, since 2010, declined to host a Frontex operation ${ }^{76}$.

72 The operational area of Poseidon Sea 2014 included sea areas between Greece and Turkey (the border along Turkey from Limnos Island in the North to Rhodes in the South also including the island of Kastellorizo and external sea border area from Karpathos at the South-East towards Crete in the South and from the South of Crete to Corfu in the Eastern Ionian Sea).

73 The operational area of JO EPN Indalo 2014 took place in Spanish territorial waters and international waters from Tarifa, in the Atlantic Ocean' side of the Strait of Gibraltar, going North-East along the coast of the Iberian Peninsula, until the border between Murcia and Alicante provinces.

74 See Regulation (EU) 604/2013 of the European Parliament and of the Council of 26 June 2013 establishing the criteria and mechanisms for determining the Member State responsible for examining an application for international protection lodged in one of the Member States by a third-country national or a stateless person (OJ L 180, 29.6.2013, p. 31). For the hierarchy of criteria for determining the Member State responsible for examining an application for international protection, see Dublin Regulation, art. $7 \mathrm{ff}$. See Giorgio GAJA, «La compétence des États dans l'examen des demandes d'asile», in Pierre D'ARGENT, Beatrice BONAFÉ and Jean COMBACAU (sous la coord. de), Les limites du droit international. Essais en l'honneur de Joe Verhoeven/The limits of international law. Essays in honour of Joe Verhoeven, Bruylant, Bruxelles, 2014, pp. 139-145.

76 For an archive of Frontex operations and the indication of the respective host country, see http://frontex.europa.eu/operations/archive-of-operations/. 
The risk of disputes between States with regard to the identification of the place of disembarkation has convinced the UNHCR of the need to develop a collaborative response to preserve the integrity of the global search and rescue regime ${ }^{77}$. With particular reference to the proposal of the Regulation on Frontex operations, the UNHCR has suggested that the operational plan could specify that disembarkation does not necessarily imply sole responsibility on the State on whose territory persons rescued at sea are disembarked ${ }^{78}$. In any case, it is evident there is a need to find new solutions with the goal to dissociate, in some instances, the acceptance of disembarkation and the assumption of responsibility for rescued persons ${ }^{79}$.

After having pointed out the strengths and the weaknesses of Regulation 656/2014, a more far-reaching reflection should be done. The Regulation only applies to Frontex-led operations and not to operations that Member States might enact unilaterally, or under other frameworks of cooperation. As has already been noted, this limitation was proffered by Member States as a condition of acceptance of the Regulation. Consequently, the advances made by the Regulation don't apply to all operations carried out in the Mediterranean Sea.

\section{THE NEW EUROPEAN BORDER AND COAST GUARD: WHAT DOES IT CHANGE FOR ASYLUM SEEKERS?}

On 15 September 2016 the European Parliament and the Council, in line with the aim of proceeding towards the gradual introduction of an integrated management system for external borders as set out in art. 77 TFEU,

77 See UNHCR, «International Cooperation to Share Burden and Responsibilities», Expert Meeting in Amman, Jordan, 27 and 28 June 2011, Discussion Paper, para. 27. As an example of a successful attempt of cooperation, UNHCR cites the case of the Spanish trawler "Francisco y Catilina» that in 2007, after rescuing 51 migrants in distress on high seas on the line between the Maltese ad Libyan SAR zones, only after high level negotiation, a burden-sharing agreement, sponsored by the European Commission, was developed to allow the disembarkation of all the persons in Malta and their processing in several European countries (Andorra, Italy, Malta and Spain). See UNHCR comments, op. cit. note 58, p. 11.

79 For a concrete proposal, in line with the relevant approach advanced by the UNHCR, see Marcello DI FILIPPO, «Delinking Disembarkation and Assumption of Responsibility for Asylum Seekers, Proposal for an EU Pilot Project not Requiring an Amendment of the Dublin Regulation», Position Paper from IIHL in the framework of the 2014 Dialogue on Protection. 
and following the provision of the creation of a European System of Border Guards as enshrined in the European Agenda on Migration ${ }^{80}$, adopted the Regulation 2016/1624 creating a European Border and Coast Guard $(\mathrm{EBCG})^{81}$.

The Regulation was adopted in record time, considering that the corresponding legislative proposal was presented by the Commission on 15 December $2015^{82}$.

The result is that, as of 6 October 2016, the national authorities responsible for border management, including coast guards to the extent that they carry out border control tasks, and the European Agency replacing Frontex (named the European Border and Coast Guard Agency) will together constitute the EBCG. Thus, the national authorities responsible for border management are set to continue to operate, and will be considered at the same time both national and European border and coast guards.

The Agency has been reinforced to oversee the effective functioning of border control at the external borders. In particular, it is now able to carry out vulnerability assessments in order to evaluate the capacity of Member States' authorities to face challenges at their external borders. Through those assessments, the Agency should address the deficiencies in the management of the external borders, provide increased operational and technical assistance to Member States' authorities. When a particular Member State does not take the necessary corrective action in line with the vulnerability assessment or in the event of disproportionate migratory pressure, the Agency could recommend the action needed and, if necessary, activate a mechanism by which the Council of EU, on the basis of a proposal of the Commission, may adopt a

80 See Communication from the Commission to the European Parliament, the Council, the European Economic and Social Committee and the Committee of the Regions, «A European Agenda on Migration», COM (2015) 240 final, 13.5.2015, p. 17.

81 See Regulation (EU) 2016/1624, cit. note 47 and hereafter «EBCG Regulation».

82 For comments to the proposal, see Sergio CARRERA and Leonhard DEN HERTOG, «A European Border and Coast Guard: What's in a Name?», CEPS Paper, núm. 88, 2016, available at https://www.ceps.eu/system/files/LSE\%20No\%2088\%20SC\%20 and\%20LdH\%20EBCG.pdf; Jorrit RIJPMA, «The proposal for a European Border and Coast Guard: evolution or revolution in external border management?», Study for the LIBE Committee, PE 556.934, 2016, p. 29, at http://www.europarl.europa.eu/ RegData/etudes/STUD/2016/556934/IPOL_STU\%282016\%29556934_EN.pdf; Philippe DE BRUYCKER, «The European Border and Coast Guard: A New Model Built on an Old Logic», European Papers, vol. 1, núm. 2, 2016, pp. 559-569, available at http:/www.europeanpapers.eu/en/system/files/pdf_version/EP_eJ_2016_2_10_ Agenda_Philippe_de_Bruyckere_1.pdf. 
decision identifying the measures to be implemented by the Agency and requiring the Member State concerned to cooperate with the Agency ${ }^{83}$.

The new Regulation makes several references to the obligation to ensure the rights of person seeking international protection.

Many of those references replicate corresponding provisions included in the Frontex Regulation, although it is evident there is an attempt to state those obligations in clearer terms.

In the framework of the new Regulation, art. 34 assumes a central position. According to this provision, the EBCG shall guarantee the protection of fundamental rights in the performance of its tasks in accordance with relevant Union law, in particular the Charter of Fundamental Rights of the EU, relevant international law, including the Convention Relating to the Status of Refugees and obligations related to access to international protection, in particular the principle of non-refoulement. The immediate consequence of this is that no person might be disembarked in, forced to enter, conducted to, or otherwise handed over or returned to the authorities of a country in contravention of the principle of non-refoulement, or from which there is a risk of expulsion or return to another country in contravention of that principle.

This provision substantially reproduces art. 1 para. 2 and art. 2 para. 1.a of the Frontex Regulation. However, it should be noted that in the framework of Frontex Regulation, the affirmation of the protection of fundamental rights and of the obligations related to access to international protection, is related to the Agency (Frontex), while the corresponding provision of the new Regulation is directed at the whole EBCG (which is composed of the national authorities responsible for border management and by the European Border and Coast Guard Agency).

Moreover, in the Frontex Regulation, the affirmation of fundamental rights protection and of the obligation related to access to international protection, follows the assertion that the responsibility for the control and surveillance of external borders lies with the Member States, while Frontex ensures the coordination of the actions of the Member States in the implementation of the measures relating to the management of external borders. Moving towards an integrated system of border management, the affirmations of both the protection of fundamental rights, as well as that regarding obligations related to access to international protection acquire a wider scope.

However it has been rightly stressed that the significant reinforcement of the task of the Agency, as well as the explicit affirmations of shared responsibility for European integrated border management, will exacerbate the existing

83 See artt. 13 and 19 of the EBCG Regulation. 
uncertainty in the allocation of accountability among the Member States participating in Frontex-coordinated joint operations ${ }^{84}$.

The new Regulation provides that members of teams shall, in the performance of their tasks and in the exercise of their powers, fully respect fundamental rights, including providing access to asylum procedures, and human dignity $^{85}$. However, the EBCG Regulation as well as the Frontex Regulation, adds that the members of the teams shall remain subject to the disciplinary measures of their home Member State in case of violations of fundamental rights or international protection obligations in the course of a joint operation or rapid border intervention ${ }^{86}$.

The provision that the operational plan for joint operations shall cover, inter alia, procedures whereby persons in need of international protection are directed to the competent national authorities for appropriate assistance is not completely new ${ }^{87}$. In the Frontex Regulation the need to regulate such procedures in the operational plan derived from the provision that the latter shall be established in accordance with Regulation 656/2014 which contains such a specification in its art. 4 para. 3. However, as we have stressed above, remitting to the operational plan - i.e. to a document which is not normally made public — the duty to regulate such important procedures is likely to be unsatisfactory and thus open to criticism.

The need to ensure that all border guards and other relevant staff who participate in the EBCG have been previously trained in fundamental rights and in access to international protection ${ }^{88}$; the need to elaborate a Code of Conduct applicable to all persons participating in the activities of EBCG with procedures intended to guarantee the principles of the rule of law and respect for fundamental rights with particular focus, inter alia, on persons seeking international protection ${ }^{89}$; the development of a Fundamental

84 See RIJPMA, op. cit. note 82, p. 29.

85 See art. 21 para. 4 of the EBCG Regulation.

86 See art. 21 para. 5 of the EBCG Regulation and art. 3 para 1.a e para. 5 of the Frontex Regulation.

87 See art. 16 para. 3 lett. 1) of the EBCG Regulation.

88 See art. 36 of the EBCG Regulation and art. 5 of the Frontex Regulation.

89 See art. 35 para. 1 of the EBCG Regulation and art. 2a of the Frontex Regulation. It shall be observed, however, that the EBCG Regulation specifies, at art. 34, that the Fundamental Rights Strategy is implemented for the purpose of guarantee the protection of fundamental rights including the obligations related to access to international protection, in particular the principle of non-refoulement. On the contrary, in the Frontex Regulation, the Fundamental Rights Strategy is more generically aimed at implementing the protection of fundamental rights. 
Rights Strategy ${ }^{90}$, are all provisions already set out in the Frontex Regulation and now reproduced in the EBCG Regulation.

Also the obligation on the Executive Director of the Agency to suspend or terminate operations where any fundamental rights violations are of a serious nature, or likely to persist, was already provided for in the Frontex Regulation ${ }^{91}$. Such a provision might be considered a genuine safeguard which could then be employed to call a halt to missions where asylum seekers' rights are at risk. It should be noted that the final version of the EBCG Regulation specifies that the Executive Director should arrive at such a decision only after consulting the Fundamental Rights Officer (FRO ${ }^{92}$.

A welcome new tool introduced by the EBCG Regulation is represented by the individual complaints mechanism which may be activated by any person directly affected by the actions of staff involved in an Agency-coordinated operation, and considers him or herself to have been the subject of a breach of his or her rights ${ }^{93}$. The claim, submitted in writing, shall be handled by the FRO who will forward all the complaints to the Executive Director of the Agency, dispatch those involved border guards to the home Member State, and inform the relevant authorities competent for fundamental rights in a Member State. Depending on whether the Agency's staff or a Member State border guard is involved, the Executive Director or the host Member State shall ensure appropriate follow-up, including disciplinary measures as necessary. When a border guard or a seconded national expert is found to have violated fundamental rights or international protection obligations, the Agency may request the Member State to remove the author of the violation from his or her post. The provision of such a procedure is a clear follow-up on the findings raised by the European Ombudsman and on the report that the latter presented to the European Parliament just a few days before the publication of the Proposal of Regulation creating an EBCG. The mere existence of a procedure for individual claims is positive. However, there can be no doubt that there is still scope to improve its functionality. For example, it has been highlighted that an administrative procedure should not substitute the right to an effective and judicial remedy ${ }^{94}$. Furthermore, leaving the ultimate deci-

\footnotetext{
90 See art. 34 of the EBCG Regulation and 26a of Frontex Regulation.

91 See art. 25 para. 4 of the EBCG Regulation and art. 3 para. 1.a and para. 5 of the Frontex Regulation.

92 The need to specify the basis upon which this assessment should be made by the Executive Director was stressed by RIJPMA, op. cit. note 82, p. 31.

93 See art. 72 of the EBCG Regulation.

94 See RIJPMA, op. cit. note 82, p. 30.
} 
sion on whether or not to remove the perpetrator of a human rights violation up to each Member State also raises criticism, considering the goal of creating an integrated management of the EU external border.

Finally, a more general issue remains open. The EBCG Regulation is based on responsibility being shared between the European Border and Coast Guard Agency and the national authorities responsible for border management, including coast guards to the extent that they carry out border controls tasks $^{95}$. In fact, the protection of external borders is a common interest of Member States and will only be feasible if the management system is conceived as a shared task among all of them in line with the principle of solidarity and responsibility to which all the EU's institutions have agreed is to be the guiding principle in addressing the migration crisis $^{96}$.

In line with this principle of solidarity that art. 67 para. 2 TFEU affirms in general terms not only with regard to strengthen external border controls, but also with regard to the policy on asylum and immigration, art. 18 of the EBCG Regulation provides that a Member State which has to face a disproportionate migratory pressure at a particular hotspot area of its external border, may request the Agency to deploy migration management support teams. Those teams could provide assistance in the screening of third-country nationals arriving at the external borders; in the provision of information to persons in clear need of international protection or to applicants or potential applicants for relocations; technical and operational assistance in the area of return.

This provision is in line with the recent experience regarding the hotspot approach, according to which the European Asylum Support Office, Frontex and Europol shall work on the ground with frontline Member States to swiftly identify, register and fingerprint incoming migrants, to channel into an asylum procedure those who are claiming international protection, to help Member States by coordinating the return of irregular migrants, to assist the host Member State with investigation to dismantle the smuggling and trafficking networks ${ }^{97}$.

95 The principle of shared responsibility is affirmed by: whereas núm. 6, 10 and 20, and by art. 5 of the EBCG Regulation.

96 See the Explanatory Memorandum that precedes the Proposal of EBCG Regulation, COM (2015) 671 final, 15.12.2015, p. 2.

97 The «Hotspot approach» has been so described by the European Agenda on Migration, cit. note $80, \mathrm{p} .6$. The position and the responsibilities of different actors involved in the hotspot approach is stressed by Federico CASOLARI, "The EU's Hotspot Approach to Managing the Migration Crisis: a Blind Spot for International Responsibility?», IybIL, núm. 25, 2015, pp. 109-134. 
There is no doubt that such a mechanism is positive in principle. However, a more ambitious solidarity mechanism should provide also for the sharing - at least in part — of the burden of the subsequent reception and integration of the persons entitled to international protection ${ }^{98}$.

It is certainly true that such a provision would be more appropriately treated in the framework of the possible revision of the Dublin Regulation. However, the Dublin IV proposal ${ }^{99}$ confined the desired solidarity between States to a distribution mechanism derived by the emergency mechanism of relocations and introduces a corrective tool that could lead to impose sanctions to non-collaborative Member States. Apart from any considerations relating to the feasibility of such a mechanism, the problem is that the Dublin IV proposal still makes the management and reception of migrants the responsibility of the most exposed Member States (i.e. the States of disembarkation).

However, a real solidarity between Member States in the management of the external borders can not be achieved if it does not provide a mechanism

98 To date the EU has introduced only an emergency solidarity mechanism deciding the relocation of 160,000 asylum applicants in clear need of international protection from Greece and Italy to the other EU Member States. See Council Decision (EU) 2015/1523 of 14 September 2015 establishing provisional measures in the area of international protection for the benefit of Italy and of Greece (OJ L 239, 15.9.2015, p. 146) and Council Decision (EU) 2015/1601 of 22 September 2015 establishing provisional measures in the area of international protection for the benefit of Italy and Greece (OJ L 248, 24.9.2015, p. 80). See Marcello DI FILIPPO, «Le misure sulla ricollocazione dei richiedenti asilo adottate dall'Unione europea nel 2015: considerazioni critiche e prospettive», Diritto, immigrazione e cittadinanza, 2015, pp. 33-60.

99 See Proposal for a Regulation of the European Parliament and of the Council establishing the criteria and mechanisms for determining the Member State responsible for examining an application for international protection lodged in one of the Member States by a third-country national or a stateless person (recast), COM (2016) 270 final, 4.5.2016. For comments to the proposal, see Francesco MAIANI, «The Reform of the Dublin III Regulation", Study for the LIBE Committee, PE 571.360, 2016, available at http://www.europarl.europa.eu/RegData/etudes/STUD/2016/571360/IPOL_ STU(2016)571360_EN.pdf; Bruno NASCIMBENE, «Refugees, the European Union and the 'Dublin System'. The Reasons for a Crisis», European Papers, vol. 1, núm. 1, 2016, pp. 101-113, available at: http://www.europeanpapers.eu/it/system/files/pdf_version/EP_eJ_2016_1_9_Agenda_Bruno_Nascimbene_4.pdf; Marcello DI FILIPPO, «Dublin 'reloaded' or time for ambitious pragmatism?', 12.10.2016, available at http:// eumigrationlawblog.eu/dublin-reloaded/. For a concrete alternative proposal, see ID., «From Dublin to Athens: A Plea for a Radical Rethinking of the Allocation of Jurisdiction in Asylum Procedures», Policy Brief, 2016, available at http://statewatch.org/ news/2016/feb/eu-from-dublin-to-athens-reforming-dublin-reg-1-16.pdf. 
whereby all the actors involved can trust each other in the knowledge that, irrespective of the place of disembarkation, the burden of asylum seekers and irregular migrants will be fairly shared between Member States.

\section{FINAL REMARKS}

Migratory flows through the Mediterranean Sea represent an as yet unanswered question faced by the European Union and its Member States.

Rescue at sea but also, unfortunately, shipwrecks with deaths and missing persons are daily news ${ }^{100}$ and increase cyclically during spring and summer seasons.

In order to assess the contribution of the European Union with regard to the interception and rescue at sea of migrants and to the consequent issues of disembarkation and taking charge of asylum seekers, the current distribution of competence between the EU and the Member States should be recalled.

The EU founding Treaties do not attribute competence for search and rescue activities to EU institutions. On the contrary, the EU institutions have expressed powers to adopt measures concerning the checks to which persons crossing external borders are subjected, and any measures necessary for the gradual introduction of an integrated management system for external borders ${ }^{101}$ : this provision applies, without distinction, to all borders and thus also concerns sea borders.

Furthermore, the EU institutions can develop a common immigration policy aimed at ensuring, at all stages, the efficient management of migration flows and the prevention of, and enhanced measures to combat, illegal immigration and trafficking in human beings ${ }^{102}$. The EU has also the competence to adopt measures that might lead to a common European asylum system ${ }^{103}$.

100 On 20 April 2016 the UNHCR reported that around 500 migrants are feared to have lost their lives in an unknown location of the Mediterranean Sea between Libya and Italy. The tragedy has been told to UNHCR staff by 41 survivors who were rescued by a merchant ship and transferred to Greece on April 16. For further details, see http:// www.unhcr.org/57178bcf6.html.

101 See art. 77 TFEU.

102 See art. 79 TFEU. The distribution of competences between the European Union and Member States in the framework of the common immigration policy is examined by Eleftheria NEFRAMI, «Répartition des competences entre l'Union européenne et ses Etats membres en matière d'immigration», Study for the LIBE Committee, PE 453.178, 2011, at http://www.europarl.europa.eu/RegData/etudes/note/ join/2011/453178/IPOL-LIBE_NT(2011)453178_FR.pdf.

103 See art. 78 TFEU. 
These broad competences relating to migration and asylum policy do not mean that currently the control and surveillance of external borders falls to the European Union. In fact, the related responsibility still lies with the Member States. For this reason, Frontex was created only to assist Member States with implementing the operational aspects of external border management and to ensure the coordination of their efforts.

Initially it was not clear whether the EU might also regulate search and rescue operations. For this reason, Decision 2010/252 adopted binding rules with regard to the interception of ships in the course of a surveillance operation in case of there being reasonable grounds for suspecting that they were carrying persons intending to enter the external sea borders irregularly, while only non-binding guidelines were dedicated to search and rescue situations and to disembarkation. On the contrary, the subsequent Regulation 656/2014 adopted a broader concept of border surveillance, one not limited to the detection of attempts at irregular border crossing, but covering - through binding rules - interception measures as well as search and rescue in the context of the EU's border control policy.

The above analysis has shown that Regulation 656/2014 takes steps forward in order to ensure that the fundamental rights of asylum seekers are respected in accordance with the ECtHR case law: the affirmation of the principle of non-refoulement is wider and is clearly extended to the operations led by Frontex, not only in territorial seas or in contiguous zone of an EU Member State, but also on the high seas. This really is important, considering that the most recent operations extended their of activity on the high seas, to just beyond the territorial waters of third States ${ }^{104}$.

Moreover, although Regulation 656/2014 does not also expressly regulate the case of operations carried out in the territorial sea of a third country, could be derived from the Frontex Regulation that EU law and the human rights of migrants shall be respected by Frontex operations in this case also.

However, there are still problematic issues in the rules governing the surveillance of the external sea border: for example, the procedural aspects of the process of identification of migrants, and the subsequent processing of asylum seekers is not regulated in detail by Regulation 656/2014, and further specifications are referred to the operational plan which, as we mentioned

104 This was the case with the Triton Operation, whose operational area, following the sea tragedies of April 2015, was extended to 138 nautical miles south of Sicily, just beyond Libyan territorial waters. 
above, isn't usually available for public scrutiny. So, the provision according to which the units participating in the Frontex operation might order an intercepted vessel to alter its course out of, or towards a destination other then, the territorial sea or the contiguous zone of the EU Member State is a cause for concern as it could be interpreted as legitimizing the practice of informal push-back.

Apart from other specific critical issues that have been stressed above, the decision to regulate search and rescue through binding rules is certainly positive. However, the uniform rules introduced by the Regulation only apply to EU-led operations and not to operations carried out by Member States unilaterally or under the aegis of other international organizations.

Nevertheless, we stressed that many actors are currently engaged across the Mediterranean Sea deploying various kinds of operations. Although the nature (military, civil, public, private) and scope of their missions (border control, search and rescue, struggle against trafficking and smuggling of migrants, commercial transports) may, in principle, differ, they are all nonetheless subject to the same international obligations concerning the duty to render assistance to any person found to be in distress at sea and to the obligations arising from human rights and refugee law. Furthermore, in practice, the different actors are often faced with the need to cooperate in order to achieve those common goals.

If the EU cannot be expected to impose its rules on every vessel travelling through the Mediterranean Sea, the EU could adopt common rules concerning search and rescue during border control operations, as well as common rules concerning the protection of asylum seekers. Those rules should be applicable to all ships operating in EU territorial waters or in the contiguous zone of a Member States and to all Member States' ships regardless of whether they are acting within the framework of a EU-coordinated operation, or individually, or within the framework of a NATO or United Nations operation and regardless of the zone of the sea in which they are operating.

In fact, it is inconceivable that a vessel of a Member State should be subjected to strict respect of the principle of non-refoulement in the case of its deployment as part of a Frontex operation (and, from October 2016, of a EBCG operation), while having the power to carry out an informal push-back were the same vessel deployed in the framework of a NATO operation. Such hypothesis is even more striking if we consider that in the current practice some countries (like Germany) are simultaneously involved in both Frontex (JO EPN Poseidon sea) and NATO operations that have been deployed side by side in the same sea crossing (the Aegean Sea). 
One may wonder if limitation of the scope of the current EU rules on surveillance of the external sea borders still remains after the creation of the EBCG. While it is certainly true that Member State will continue to retain the primary responsibility for the management of their section of the external borders ${ }^{105}$, the institution of an EBCG aims to establish a shared management of external borders. In such a scenario, limiting the application of uniform rules on interception, search and rescue and disembarkation to Frontex operations only, becomes even less acceptable ${ }^{106}$.

The EBCG Regulation incorporates many improvements that have been made to the functioning of Frontex in order to bring its activity in line with the fundamental rights of migrants, and of asylum seekers ${ }^{107}$.

The individual complaints mechanism is an important tool, foreseen by the EBCG Regulation, which asylum seekers could avail themselves of and which could be activated by any person who is directly affected by the actions of staff involved in an Agency-coordinated operation and considers themselves to have been the subject of a breach of their rights. Although concerns have been rightly expressed because the new complaint mechanism would not be independent from the EBCG Agency, would not be judicial in nature and would not allow for effective remedies to complainants in the event of unfavorable or negative decisions ${ }^{108}$, it is undeniable that simply the introduction of this new tool is a step in the right direction towards a strengthening of migrants' rights as was also suggested by the EU Ombudsman.

With regard to the EBCG Regulation we have stressed that a more ambitious solidarity mechanism should have been provided for. In fact, the Regulation foresees that the new Agency might deploy migration management support teams in the event of disproportionate migratory pressure at an external border. In principle, this provision has to be welcomed as it might entail real aid in favour of Member States more exposed to migratory flows in managing the operations of identification and initiating the asylum process. However, provided that this mechanism could be deployed only in exceptional situations and not for the ordinary management of migratory flows, is a cause for concern. Moreover, in the final version of the EBCG Regulation, the decision

105 See whereas núm. 6 and art. 5 of the EBCG Regulation.

106 In the same vein, see CARRERA and DEN HERTOG, "A European Border...», op. cit. note 82 .

107 See, in particular, section VI.

108 See, Elspeth GUILD, Evelien BROUWER, Kees GROENENDIJK, Sergio CARRERA, "What is happening to the Schengen borders?», CEPS Paper, núm. 86, 2015, p. 21, available at https://www.ceps.eu/system/files/No\%2086\%20Schengenland_0. pdf. 
to authorize the deployment of such support teams when the interested Member State has not requested support from the Agency is up to the Council of the EU, with the consequence that it is to be expected that political discretion will play an important role in deciding whether to activate the mechanism.

A more ambitious solidarity mechanism should be provided for not only for dealing with emergency situations, but also for assisting Member States at the EU's external borders with the ordinary management of reception of persons entitled to international protection, and for allowing to share - at least in part - the burden of the consequent need for integration of those migrants.

This issue would be more appropriately managed in the framework of the possible revision of the Dublin Regulation, but it is evident that, depending on which Member State will end up with responsibility for processing an asylum application, questions related to the identification of a place of disembarkation for persons rescued at sea will also be dealt in a different way. In fact, each Member State will be willing to participate in operations of interception and search and rescue of migrants at sea, only relying on the knowledge that the burden of asylum seekers and irregular migrants will be determined irrespective of the place of disembarkation.

The right to seek asylum must be ensured by the EU Member States through a fair procedure according to the guarantees provided by Directive 2013/32/EU (e.g., the right to access to the services of an interpreter, the opportunity to communicate with a representative of the UNHCR and to consult a legal advisor, the right to an effective judicial remedy ${ }^{109}$ ). These guarantees must be provided regardless of the Member State where the application of asylum is presented and regardless of the agreements the EU has eventually concluded with third countries.

In particular, the latter issue recently raised with reference to the EU-Turkey statement of 18 march $2016^{110}$, according to which all new irregular

109 See Directive 2013/32/EU of the European Parliament and of the Council of 26 June 2013 on common procedures for granting and withdrawing international protection (recast) (OJ L 180, 29.6.2013, p. 60), whereas núm. 25.

110 The statement is available at http://www.consilium.europa.eu/en/press/press-releases/2016/03/18-eu-turkey-statement/. With regard to the discussed legality of the statement, see the forum available at http://verfassungsblog.de/tag/eu-turkey-agreement/. See also UNHCR, «Legal considerations on the return of asylum-seekers and refugee from Greece to Turkey as part of the EU-Turkey Cooperation in Tackling the Migration Crisis under the safe third country and first country of asylum concept", available at http://www.unhcr.org/56f3ec5a9.pdf; Enzo CANNIZZARO, «Disintegration through Law?», European Papers, vol. 1, núm. 1, 2016, pp. 3-6; Chiara FA- 
migrants crossing from Turkey into the Greek islands as from 20 March 2016 will be returned to Turkey. The parties have specified that those readmissions will take place in full accordance with EU and international law (including respect for the principle of non-refoulement), that any kind of collective expulsion will be excluded and that migrants arriving in the Greek islands will be duly registered and any application for asylum will be processed individually by the Greek authorities in accordance with the above mentioned asylum procedures Directive, in cooperation with the UNHCR.

Such specifications have been introduced with the intention of preventing the more predictable criticisms. However, it has been noted that, according to the EU-Turkey statement, is not clear what the treatment of those migrants intercepted before they reach the Greek island will be ${ }^{111}$. In fact, the statement provides that only migrants «arriving in the Greek islands will be duly registered, and any application for asylum will be processed individually». No explicit reference is made to migrants intercepted in Greek territorial waters or on the high seas or in Turkish waters. In our view, there is no doubt that the procedure established by Directive 2013/32/EU shall be applied wherever a Member State exercises its jurisdiction over migrants. However, it is undeniable that the statement could be formulated in such a way to avoid any doubt.

Another critical issue is represented by the choice of Turkey as a reliable partner. Although the EU has recognized that Turkey is making commendable efforts to provide massive humanitarian aid and support to people seeking refuge from Syria ${ }^{112}$, and although Turkey recently revised its national legislation in order to facilitate the granting of temporary protection to Syrian

VILLI, «La cooperazione UE-Turchia per contenere il flusso dei migranti e richiedenti asilo: obiettivo riuscito?», Diritti umani e Diritto internazionale, 2016, pp. 405-426; Henri LABAYLE and Philippe DE BRUYCKER, «The EU-Turkey Agreement on migration and asylum: False pretences or a fool's bargain?», 1.4.2016, available at http://eumigrationlawblog.eu/the-eu-turkey-agreement-on-migration-and-asylumfalse-pretences-or-a-fools-bargain/\#comments; Steve PEERS, «The draft EU/Turkey deal on migration and refugees: is it legal?», 16.3.2016, available at http://eulawanalysis.blogspot.it/2016/03/the-draft-euturkey-deal-on-migration.html. With regard to the specific issue of the real nature of the EU-Turkey statement, see Maarten DEN HEIJER and Thomas SPIJKERBOER, «Is the EU-Turkey refugee and migration deal a treaty?», 7.4.2016, available at http://eulawanalysis.blogspot.it/2016/04/is-eu-turkey-refugee-and-migration-deal.html.

111 See PEERS, "The draft ...», op. cit. note 110.

112 See EU-Turkey joint action plan, Brussels, 15.10.2015, available at http://europa.eu/ rapid/press-release_MEMO-15-5860_it.htm\#_ftnref1. 
nationals ${ }^{113}$, concern still remains as regards considering Turkey a safe third country as defined by the asylum procedures Directive. In this regard, it is significant that the Commission is still requiring assurances from Turkey about temporary protection to non-Syrians, who, according to the statement of 18 March 2016 are being returned and, more generally, about ensuring that asylum seekers receive the necessary protection in Turkey if needed ${ }^{114}$.

Also the provision of the EU-Turkey statement according to which Turkey will take any necessary measures to prevent new sea or land routes for illegal migration opening from Turkey to the EU is cause of some concern. Notwithstanding that the prevention of irregular migration is certainly a priority for the European Union, this goal should not be achieved through «any necessary measures to prevent new arrivals». The EU is founded on certain core values such as respect for human dignity, the rule of law and the respect for human rights ${ }^{115}$. It is not acceptable that these values risk being violated by the EU by supporting the conduct of third countries entrusted with doing the «dirty work».

113 In particular, the European Commission reported that on 6.4.2016 Turkey adopted a law to clarify that Syrian nationals returning under the EU-Turkey arrangements may request and be granted temporary protection, covering both previously registered and non-registered Syrians in Turkey. See Communication from the Commission to the European Parliament, the European Council and the Council, «First report on the progress made in the implementation of the EU-Turkey Statement», COM (2016) 231 final, 20.4.2016, at p. 4

114 See «First report on the progress made in the implementation of the EU-Turkey Statement», cit. note 113 , p. 4 and p. 12.

115 See art. 2 TEU. 
